\title{
GAYA HIDUP HEDONIS DAN IMPULSE BUYING PADA KALANGAN REMAJA PUTRI
}

\section{Estalita Kelly}

\author{
Dosen Fakultas Psikologi Universitas Yudharta Pasuruan
}

\begin{abstract}
ABSTRAK
Era globalisasi yang membawa ritel modern menjadi berkembang pesat dan pada akhirnya menjadikansemakin ketatnya persaingan di Industri ritel modern di Indonesia.Munculnya pemain baru dalam industri ini semakin memperketat persaingan.Ada yang menarik dari perilaku konsumen di ritel modern salah satunya yakni Impulse Buying. Selain itu, berbagai macam produk diciptakan demi untuk memenuhi kebutuhan konsumen, namun dewasa ini, tidak hanya produk yang sifatnya sebagai pemenuhan kebutuhan melainkan pada pemuas kebutuhan.Target pemasaran dari produk tersebut tidak lepas dari perilaku konsumen.Kegiatan berbelanja seseorang di motivasi oleh motif yg bersifat rasional yang berkaitan dg manfaat yg diberikan produk tersebut. Namun ada nilai lain yang turut mempengaruhi yakni nilai yang bersifat emosional (hedonis).

Tujuan penelitian untuk mengetahui hubungan hubungan gaya hidup hedonis dengan impulse buying pada kalangan remaja putri. Subyek penelitian sebanyak 100 siswi yang diambil secara acak (Random sampling). Hasil penelitian menunjukkan rxy sebesar 0,983 lebih besar dari $r$ tabel $1 \%$ sebesar 0,25 6. Hal ini mengindikasikan bahwa ketika gaya hidup hedonis tinggi maka impulse buying cenderung juga akan tinggi, dan sebaliknya. Hal tersebut juga di dukung dengan hasil Freg sebesar 89,65 dengan db 1 lawan 98 diperoleh $\mathrm{F}$ tabel 1\% sebesar 6,63, artinya gaya hidup hedonis dapat meramalkan impulse buying (Y) dengan demikian 96,63\% impulse buying disebabkan oleh gaya hidup hedonis.
\end{abstract}

Kata Kunci: Gaya Hidup Hedonis, Impulse Buying.

\section{LATAR BELAKANG}

Semakin terbukanya peluang bisnis bagi pengusaha asing untuk berekspansi mengembangkan bisnis ritelnya di Indonesia dan upaya yang dilakukan oleh pemerintah untuk mendorong perkembangan bisnis ritel mengakibatkan tumbuhnya ritel modern yang begitu pesat. Pernyataan ini diperkuat dengan data hasil survey yang dilakukan oleh Nielsen Media Research dan Retail Asia Magazine yaitu jumlah gerai hypermarket di tahun 2008 meningkat sekitar 25 persen dari 109 menj adi 146 unit; sementara supermarket pertumbuhannya lebih cepat yakni sekitar 29 persen dari 85 menjadi 120 .
Saat ini kegiatan pemasaran tidak bisa dipisahkan dari perilaku konsumen sebagai target pasar suatu perusahaan. Indonesia merupakan negara berkembang yang menj adi target potensial dalam pemasaran produk, baik dari perusahaan lokal maupun internasional. Agar perusahaan tersebut menuai kesuksesan di Indonesia, maka perlu mempelajari karakter unik yang dimiliki konsumen Indonesia (Irawan, 2007). Seperti tertulis dalam salah satu artikel yang mengatakan bahwa salah satu dari sepuluh karakter unik konsumen Indonesia adalah cenderung tidak memiliki perencanaan. Konsumen Indonesia termasuk konsumen yang 
tidak terbiasa merencanakan sesuatu.

Sekalipun merencanakan, namun mereka akan memutuskan pada saat-saat terakhir. Salah satu bentuk perilaku konsumen yang tidak punya rencana adalah impulse buying (membeli tanpa rencana) (Marketing.co.id, 2012). Bahkan berdasarkan survei Nielsen, ternyata $85 \%$ pembelanja ritel modern cenderung untuk berbelanja sesuatu yang tidak direncanakan.

Hampir dari kita mungkin pernah melakukan hal tersebut, yakni, seringkali seseorang yang belanja di pasar swalayan atau mall, membeli barang di luar rencana semula. Walaupun daftar belanja sudah dicatat rapi, berangan-angan dengan barang yang hendak dibeli, seperti di luar kesadaran, masih saja mereka membeli yang tidak ada dalam daftar itu. Tentunya, bagi yang tidak terbiasa mencatat daftar barang yang hendak dibeli, potensi berbelanja di luar rencana jauh lebih besar. Bisa juga dengan hanya melihat-lihat kemudian langsung tertarik, ataupun mungkin karena adanya pengaruh lingkungan sekitar, sehingga kita mudah tergiur untuk memiliki suatu barang dan segera membelinya tanpa melihat dampak yang di dapatkan.

Manusia memiliki berbagai sikap dalam mengkonsumsi barang. Ada yang mengkonsumsi karena kebutuhan, kelompok, kesenangan sesaat, mengikuti trend, dan lainlain. Menurut Tambunan (dalam Nukman dkk, 2011) kata "konsumtif" sering diartikan sama dengan kata "konsumerisme" padahal kata yang terakhir ini mengacu pada segala sesuatu yang berhubungan dengan seseorang. Sedangkan konsumtif lebih khusus (impulse buying) menjelaskan keinginan untuk mengkonsumsi barang -barang yang sebenarnya kurang diperlukan secara berlebihan untuk mencapai kepuasan yang maksimal.

Menurut Kharis (2011) menyebutkan bahwa impulse buying atau biasa disebut juga unplanned purchase, adalah perilaku orang dimana orang tersebut tidak merencanakan sesuatu dalam berbelanja. Konsumen melakukan impulse buying tidak berpikir untuk membeli suatu produk atau merek tertentu. Mereka langsung melakukan pembelian karena ketertarikan pada merek atau produk saat itu juga. Kegiatan berbelanja seseorang pada awalnya dimotivasi oleh motif yang bersifat rasional, yakni berkaitan dengan manfaat yang diberikan oleh produk tersebut (nilai utilitarian). Namun, ada nilai lain yang turut mempengaruhi kegiatan belanja seseorang, yakni nilai yang bersifat emosional atau yang dikenal dengan istilah hedonis. Menurut Silvera et al. (dalam Yistiani et al, 2012:3) pembelian impulsif adalah kesenangan yang didorong oleh pencapaian tujuan yang bersifat hedonik.

Pada saat seseorang berbelanja, tentunya konsumen akan memperhatikan aspek-aspek kenikmatan dan kesenangan (hedonis) tersebut, disamping manfaat yang diperoleh dari produk itu sendiri. Menurut Ma'aruf (2006) dalam Yistiani (2012) dikaitkan dengan konsumen Indonesia, kebanyakan mereka saat ini berorientasi rekreasi yang mementingkan aspek kesenangan, kenikmatan, dan hiburan saat berbelanja. 
Perilaku pembelian impulsif maupun motivasi yang bersifat emosional memiliki keterkaitan satu sama lain. Kebanyakan seseorang yang memiliki gairah emosional sering mengalami pengalaman berbelanja secara hedonis (Hirschman dan Holbrook, 1982 dalam Gültekin dan Özer, 2012). Rook (Park et al, 2006) menyebutkan bahwa perilaku pembelian impulsif sering dipengaruhi oleh beberapa hal, salah satunya adalah pengalaman yang bersifat hedonik. Hubungan ini dapat diasumsikan apabila pelanggan merasa senang dan merasa nyaman saat berbelanja di suatu gerai maka kemungkinan untuk melakukan pembelian yang bersifat impulsif juga akan semakin meningkat.

Pernyataan ini didukung oleh penelitian yang dilakukan oleh Rachmawati (2009) yang menunjukan bahwa faktor internal seperti hedonic shopping value dan emosi positif secara signifikan mempengaruhi pembelian impulsif. Selain itu adanya faktor hedonic motive yakni motivasi seseorang untuk berbelanja, karena berbelanja merupakan suatu kesenangan tersendiri sehingga tidak memperhatikan manfaat dari produk yang dibeli.

\section{Menurut Hirsman dan Holbrook} (Fitriani, 2010), konsumen yang berbelanja untuk rekreasi tentunya mengharapkan hedonic consumption tendency yang tingkatannya lebih tinggi, dimana hedonic consumption tendency tersebut merupakan pengalaman konsumsi yang berhubungan dengan pancaindera, perasaan, fantasi dan kesenangan yang akan mempengaruhi emosi seseorang. Keinginan konsumen untuk mencari konsumsi hedonis dalam berbelanja tersebutlah dapat menghasilkan adanya pembelian impulsif (Park et al.,2006).

Hasil yang sama juga diperoleh dalam sebuah studi yang dilakukan oleh Hausman (Rohman,2009) yang menemukan bahwa konsumen yang berbelanja untuk memuaskan keinginan hedonisnya seperti mencari pengalaman baru, mencari variasi dan kesenangan ternyata secara signifikan berpengaruh terhadap terhadap pembelian impulsif.

Pada kondisi ini, diduga hedonistik erat melekat dalam hidup seseorang. Kelekatan itu berupa seringnya kita terjebak dalam pola hidup Hedonis. Pola hidup seperti ini mudah dijumpai dalam kehidupan sehari-hari, dimana orientasi hidup selalu diarahkan pada kenikmatan, kesenangan atau menghindari perasaan-perasaan tidak enak.Gambaran mengenai gaya hidup hedonis menurut Susianto \& Harjanti (2006)memiliki ciri-ciri antara lain: mengerahkan aktivitas untuk mencapai kenikmatanhidup, sebagian besar perhatiannya ditujukan keluar rumah, merasa mudah bertemanwalaupun memilih-milih, menjadi pusat perhatian, saat luang hanya untuk bermaindan kebanyakan anggota kelompok adalah orang yang berada. Selain itu, status sebagai logika seseorang, ternyata merupakan halyang lebih masuk akal dari pada alasan fungsional. Pendapat tersebut mengartikanbahwa usaha untuk memiliki suatu barang atau jasa bukan berdasarkan pada kebutuhan fungsional melainkan lebih dari pada kebutuhan keinginan. 
Dewasa ini berbagai macam produk ditawarkan kepada seseorang. Produk-produk ini bukan hanya barang yang dapat memuaskan kebutuhan seseorang, tetapi terutama produk yang dapat memuaskan kesenangan seseorang. Informasi mengenai produk: baik melalui iklan, promosi langsung maupun penjualan secara langsung berkembang semakin bervariasi, gencar, dan menggunakan teknologi yang mutakhir dan canggih. Gaya hidup dan kebiasaan seorang dapat berubah dalam jangka waktu yang singkat mengarah pada kehidupan mewah dan cenderung berlebihan.

Gaya hidup merupakan wujud dari suatu reaksi dari aktivitas, minat, dan opini. Oleh karena itu dapat dikatakan jika seseorang menghabiskan banyak waktu dan uang untuk hal-hal yang tidak berguna, tidak sesuai dengan kebutuhan terlebih lagi hanya untuk kesenangan semata, maka gaya hidup seperti ini dapat dikategorikan sebagai perilaku impulse buying (Sallina, 201 1). Gaya hidup hedonis yang orientasinya kesenangan banyak di temukan dikalangan remaja. Menurut Monks (Masmuadi \& Rachmawati, 2009) remaja memang menginginkan agar penampilan, gaya tingkah laku, cara bersikap, dan lain-lainnya akan menarik perhatian orang lain, terutama kelompok teman sebaya. Remaja ingin diakui eksistensinya oleh lingkungan sosialnya berusaha untuk mengikuti perkembangan yang terjadi seperti cara berpenampilan.

Kebutuhan untuk diterima dan menjadi sama dengan orang lain atau kelompok teman sebaya menyebabkan remaja berusaha untuk mengikuti berbagai atribut yang sedang tren, misalnya saja pemilihan model pakaian dengan merek terkenal, penggunaan telepon genggam (HP) dengan fasilitas layanan terbaru, berbelanja di pusat perbelanjaan seperti mall ataupun berbelanja di pasar tradisional atau sekedar jalan-jalan untuk mengisi waktu luang bersama kelompok teman sebaya dan sebagainya. Kelompok masyarakat yang menj adi target potensial dalam pemasaran produk, baik produk dari perusahan lokal maupun internasional, adalah masyarakat yang berada pada kelompok usia remaja (Mangkunegara, 2005).

Pada masa remaja, mereka sedang pada tahap mencari identitas sehingga mereka menciptakan sesuatu hal yang berbeda, baik dari sisi gaya pakaian, gaya rambut, cara berdandan, maupun bertingkah laku. Remaja juga cenderung untuk memiliki keingintahuan yang lebih akan halhal yang baru sehingga mereka tidak ragu untuk mencobanya (Sholihah \& Kuswardani, 2005). Selain itu, remaja biasanya mudah dipengaruhi oleh rayuan iklan, mudah terpengaruh oleh perubahan, serta cenderung boros dalam menggunakan uangnya (Sari, 2009).

Remaja umumnya membeli sesuatu tidak berdasarkan kebutuhan, akan tetapi lebih mengarah pada pemenuhan kebutuhan psikologis. Artinya, berbelanja tidak hanya sekedar untuk mendapatkan produk yang dinginkan, melainkan berbelanja telah menjadi suatu aktivitas yang sifatnya rekreasi untuk mendapatkan kepuasan, berupa motif-motif sosial dan personal (Ekowati, 2009). 


\section{KAJIAN TEORI}

\section{Impulse Buying}

Solomon \& Rabolt (2009) menyatakan bahwa impulse buying adalah suatu kondisi yang terjadi ketika individu mengalami perasaan terdesak secara tiba-tiba yang tidak dapat dilawan.Sedangkan Kharis (2011) menyebutkan bahwa impulse buying atau biasa disebut juga unplanned Purchase, adalah perilaku orang dimana orang tersebut tidak merencanakan sesuatu dalam berbelanja.

Beberapa peneliti pemasaran beranggapan bahwa impulse bersinonim dengan unplanned ketika para psikolog dan ekonom memfokuskan pada aspek irasional atau pembelian impulsif murni (Semuel, 2006). Semuel (2006) juga mengemukakan bahwa ketika terjadi pembelian impulsif akan memberikan pengalaman akan kebutuhan emosional. Konsumen yang tertarik secara emosional (terutama untuk produk involvement) seringkali tidak lagi melibatkan rasionalitas dalam proses pengambilan keputusan pembelian (Rachmasari, 2010).

Menurut Mowen dan Minor (2001) dalam Gültekin dan Özer (2012) definisi Pembelian impulsif (Impulse Buying) adalah tindakan membeli yang dilakukan tanpa memiliki masalah sebelumnya atau maksud ataupun niat membeli yang terbentuk sebelum memasuki toko. Sedangkan menurut Rook dan Fisher (Kharis, 2011), impulse buying memiliki beberapa karakteristik, yaitu pertama, spontanitas. Kedua, kekuatan, kompulsif, dan intensitas. Ketiga, kegairahan dan stimulasi.Keempat, ketidak pedulian akan akibat.
Perilaku impulse buying berkaitan erat dengan proes keputusan pembelian. Menurut Assael (2009), tingkat keinginan seseorang menempati tempat yang paling tinggi dalam pembelian. Assuari menambahkan bahwa perilaku ini dapat terjadi karena adanya faktorfaktor sebagai berikut:

a. Pembelian ingin tampak berbeda dari yang lain.

b. Ikut-ikutan, contohnya seseorang melakukan tindakan pembelian hanya untuk meniru orang lain atau kelompoknya dan mengikuti mode yang sedang beredar.

Menurut Loudon \& Bitta (Widawati, 2011), faktor-faktor yang mempengaruhi impulse buying adalah karakteristik konsumen. Karakteristik konsumen meliputi pengalaman belajar, kepribadian, dan konsep diri atau citra diri. Hawkins (2007) juga menambahkan karakteristik situsional sebagai faktor yang juga berpengaruh.

1. Karakteristik produk yang mempengaruhi impulse buying adalah:

a. Memiliki harga yang rendah

b. Adanya sedikit kebutuhan terhadap produk tersebut

c. Ukurannya kecil dan ringan serta mudah disimpan

2. Pada karakteristik pemasaran, hal-hal yang mempengaruhi impulse buying adalah:

d. Distribusi massa pada self service outlet terhadap pemasangan iklan besar-besaran dan material yang akan didiskon. Hawkins dkk (2007) juga menambahkan mengenai 
ketersediaan informasi dimana hal ini meliputi suatu format yang secara langsung berhubungan dengan penggunaan informasi. Bagaimanapun juga, terlalu banyak informasi dapat menyebabkan informasi yang berlebihan dan penggunaan informasi berkurang. Pemasangan iklan, pembelian barang yang dipamerkan, website, penjaga toko, paket-paket, konsumen lain, dan sumber yang bebas seperti laporan konsumen adalah sumber utama dari informasi konsumen.

e. Posisi barang yang dipamerkan dan lokasi toko yang menonjol turut mempengaruhi impulse buying. Hawkins dkk (2007) juga menambahkan bahwa jumlah, lokasi, dan jarak antara toko barang eceran di pasar mempengaruhi jumlah kunjungan konsumen ke toko sebelum pembelian. Karena kunjungan ke toko membutuhkan waktu energi, dan uang, jarak kedekatan dari toko seringkali akan meningkatkan aspek ini dari pencarian di luar.

3. Karakteristik konsumen yang mempengaruhi impulse buying adalah:

\section{a. Kepribadian konsumen}

b. Demografis berupa gender, usia, kelas sosial ekonomi, status perkawinan, pekerjaan, dan pendidikan.

\section{Gaya Hidup Hedonis}

Gaya hidup merupakan suatu perpaduan antara kebudayaan ekspresi diri dan harapan kelompok terhadap seseorang dalam bertindak berlaku (Masmuadi \& Rachmawati, 2009). Lebih lanjut Masmuadi \& Rachmawati (2009) mengatakan bahwa gaya hidup adalah cara mengekspresikan diri agar sesuai dengan caracara seperti apa seseorang ingin dipersepsikan sehingga dapat diterima oleh kelompok sosial tertentu. Ancok (2004), berpendapat bahwa gaya hidup merupakan pengaruh dari adanya modernisasi.

Menurut Takariani (2013) hedonisme dalam bahasa Yunani, hedone berarti kenikmatan, kegembiraan) adalah gaya hidup yang menjadikan kenikmatan atau kebahagiaan sebagai tujuan. Aktivitas apa pun yang dilakukan hanya demi mencapai kenikmatan, bagaimanapun caranya, apa pun sarananya, dan apa pun akibatnya. Orientasi hidup selalu diarahkan ke sana dengan sedapat-dapatnya menghindari perasaan-perasaan yang tidak enak atau menyakitkan. Menurut Rianto (2005) gaya hidup hedonisadalah pola perilaku yang dapat diketahui dari aktifitas, minat maupun pendapat yang selalu menekankan pada kesenangan hidup. Munandar (2012) menjelaskan bahwa gaya hidup hedonisadalah pola hidup yang mengarahkan aktivitasnya untuk mencari kesenangan hidup dan aktivitas tersebut berupa mengabiskan waktu di luar rumah, lebih banyak bermain, senang pada keramaian kota, senang membeli barang yang kurang diperlukan dan selalu ingin menjadi pusat perhatian.

Menurut Loudon dan Bitta (Martha dkk, 2008), faktor-faktor yang mempengaruhi gaya hidup adalah budaya, nilai, demografik, kelas sosial, kelompok rujukan atau kelompok 
acuan, keluarga, kepribadian, motivasi dan emosi. Martha dkk (2008) menyebutkan mengenai aspek gaya hidup hedonis, yaitu terdiri dari tiga aspek yaitu aktivitas, minat dan pendapat, kemudian aspeknya diwujudkan dalam bentuk suka mencari perhatian, boros, memilih-milih teman, dan waktu luang dihabiskan dengan bersenang-senang

Karakteristik dari individu yang memiliki gaya hidup hedonis menurut Surindo (Masmuadi \&Rachmawati, 2007) adalah suka mencari perhatian, cenderung impulsive, kurang rasional, cenderung follower dan mudah dipengaruhi. Selain itu, terdapat atributatribut gaya hedonis ditunjukkan dengan lebih senang mengisi waktu luang di tempat yang santai seperti cafe. serta orang-orang yang menganut alliran hedonis biasanya boros, memburu kesenangan tanpa memperhitungkan halal-haramnya.

\section{Remaja}

Remaja berasal dari kata

Latin adolensence yang berarti tumbuh atau tumbuh menjadi dewasa. Istilah adolensence mempunyai arti yang lebih luas lagi yang mencakup kematangan mental, emosional sosial dan fisik. Pada masa ini sebenarnya tidak mempunyai tempat yang jelas karena tidak termasuk golongan anak tetapi tidak juga golongan dewasa atau tua.

Banyak tokoh yang memberikan definisi tentang remaja, seperti Santrock (2007) yang mendefinisikan remaja sebagai periode pertumbuhan antara masa kanak-kanak dengan masa dewasa. Papalia, Old dan Feldman (2008) menyebutkan masa remaja merupakan masa transisi antara masa kanak-kanak dan masa dewasa yang mengandung perubahan besar baik secara fisik, kognitif maupun psikososial. Masa remaja dimulai dengan pubertas, yaitu proses yang mengarah kepada kematangan seksual atau fertilitas (kemampuan untuk bereproduksi).

Menurut John W. Santrock (2007) masa remaja adalah peralihan dari masa anak-anak ke masa dewasa yang mengalami perkembangan dalam semua aspek / fungsi untuk memasuki masa dewasa. (Sarwono, 2006) mendefinisikan remaja berdasarkan definisi konseptual World Health Organization (WHO) yang mendefinisikan remaja berdasarkan 3 (tiga) kriteria, yaitu : biologis, psikologis, dan sosial ekonomi.

1. Remaja adalah masa ketika individu berkembang dan menunjukkan tandatanda seksual sekunder hingga saat individu mencapai kematangan seksual.

2. Remaja adalah masa saat individu mengalami perkembangan psikologis dan pola identifikasi dari masa kanakkanak menjadi dewasa.

3. Remaja adalah suatu masa ketika terjadi peralihan dari ketergantungan sosialekonomi yang penuh kepada keadaan yang relatif lebih mandiri.

Hurlock (2004) mengatakan bahwa secara umum masa remaja dibagi menjadi tiga bagian, yaitu sebagai berikut:

1. Masa remaja awal (12-15 tahun)

Pada masa ini remaja mulai meninggalkan perannya sebagai anak-anak dan berusaha mengembangkan diri sebagai individu yang unik dan tidak tergantung pada 
orang tua

2. Masa remaja pertengahan (15 - 18 tahun) Ditandai oleh perkembangan kemampuan berfikir yang baru. Teman sebaya memiliki peran yang penting. Pada masa ini, remaja juga mengembangkan kematangan tingkah laku, belajar membuat keputusan sendiri, dan selain itu, penerimaan dari lawan jenis menjadi penting bagi individu.

3. Masa remaja akhir (19-21 tahun)

Pada masa ini ditandai dengan persiapan akhir untuk memasuki peran-peran orang dewasa. Keinginan yang kuat untuk menjadi matang dan diterima oleh kelompok teman sebaya dan diterima orang dewasa.

\section{Gaya Hidup Hedonis Dan Impulse Buying Di Kalangan Remaja Putri.}

Kegiatan pemasaran tidak bisa dilepaskan dari perilaku konsumen sebagai target pasar suatu perusahaan. Salah satu bentuk perilaku konsumen yakni terjadinya impulse buying (membeli tanpa rencana). Seperti yang tertulis dalam salah satu artikel yang mengatakan bahwa salah satu dari sepuluh karakter unik konsumen Indonesia adalah cenderung tidak memiliki perencanaan dalam berbelanja.

Kegiatan berbelanja seseorang pada awalnya dimotivasi oleh motif yang bersifat rasional, yakni berkaitan dengan manfaat yang diberikan oleh produk tersebut (nilai utilitarian). Namun ada nilai lain yang turut mempengaruhi kegiatan belanja seseorang, yakni nilai yang bersifat emosional atau yang dikenal dengan istilah hedonis. Dimana kebanyakan seseorang yang memiliki gairah emosional, sering mengalami pengalaman berbelanja secara hedonis (Hirschman dan Holbrook, 1982 dalam Gültekin dan Özer, 2012). Semuel (2006) juga mengemukakan bahwa ketika terjadi pembelian impulsif akan memberikan pengalaman akan kebutuhan emosional.

Hausman (Park et al., 2006) menemukan bahwa perilaku pembelian impulsif dilakukan konsumen untuk memuaskan hasrat hedonik yaitu kesenangan, menemukan dan merasakan hal-hal baru, fantasi, interaksi sosial, dan emosional. Penelitian tersebut menunjukkan bahwa nilai yang bersifat emosional (hedonik) mendorong terjadinya pembelian impulsif. Konsumen yang berbelanja untuk memuaskan keinginan hedonisnya seperti mencari pengalaman baru, mencari variasi dan kesenangan ternyata secara signifikan berpengaruh terhadap pembelian impulsif (Hausman, dalam Rohman (2009). Selain itu, faktor hedonic motive yakni motivasi seseorang untuk berbelanja, karena berbelanja merupakan suatu kesenangan tersendiri sehingga tidak memperhatikan manfaat dari produk yang dibeli (Rahmawati, 2007).

Kebiasaan dan gaya hidup seseorang mengalami perubahan dalam waktu yang relatif singkat menuju kehidupan yang mewah dan berlebihan. Gaya hidup merupakan wujud dari suatu reaksi dari aktivitas, minat, dan opini. Oleh karena itu, dapat dikatakan jika seseorang menghabiskan banyak waktu dan uang untuk hal-hal yang tidak berguna, tidak sesuai dengan kebutuhan terlebih lagi hanya untuk kesenangan semata, maka gaya hidup 
seperti ini dapat dikategorikan sebagai perilaku impulse buying (Sallina, 2011).

Manakala gaya hidup merupakan sesuatu yang dianggap penting dan menjadi prestige yang mengutamakan faktor

kesenangan akan mengarah pada kecenderungan yang bersifat hedonis (Masmuadi \&Rachmawati, 2007). Gaya hidup hedonis yang berorientasi pada kesenangan, umumnya banyak di temukan dikalangan remaja pembeli dengan umur lebih muda mempunyai kecenderungan perilaku impulsif lebih besar dari kelompok umur diatasnya. Hal tersebut dikarenakan remaja masa kini dihadapkan pada pilihan gaya hidup yang kompleks. Remaja yang masih pada tahap pencarian identitas diri, jadi banyak meniru apa yang dilihat dan didengar dari lingkunganya (Lumintang, 2010)

Menurut Susanto (2006) hal ini karena remaja mulai mencari identitas diri melalui penggunaan simbol status seperti mobil, pakaian, dan pemilikan barang-barang lain yang mudah terlihat. Remaja yang menganggap bahwa penampilan dan gaya hidup mewah merupakan simbol status yang lebih tinggi dalam kelompoknya. Hal ini menimbulkan adanya sikap untuk bersaing dalam penampilan diri seperti memakai pakaian bermerek dan modis, gaya rambut, dan barang-barang mewah lainnya. Kecenderungan perilaku ini akan mengarah pada hanya mementingkan faktor keinginan (want) dari pada kebutuhan (need) yang mengutamakan pada kesenangan pada materi.

Remaja juga cenderung untuk memiliki keingintahuan yang lebih akan hal-hal yang baru sehingga mereka tidak ragu untuk mencobanya (Sholihah \& Kuswardani, 2005). Selain itu, remaja biasanya mudah dipengaruhi oleh rayuan iklan, mudah terpengaruh oleh perubahan, serta cenderung boros dalam menggunakan uangnya (Sari, 2009). Hal ini didukung oleh Mangkunegara (2005) bahwa kelompok masyarakat yang menj adi target potensial dalam pemasaran produk, baik produk dari perusahan lokal maupun internasional, adalah masyarakat yang berada pada kelompok usia remaja.

\section{Hipotesis}

Hipotesis penelitian adalah : gaya hidup hedonis dapat meningkatkan impulse buying pada kalangan remaja putri.

\section{METODE PENELITIAN}

\section{Subjek Peneitian}

Karakteristik subjek penelitian ini adalah siswa SMA Ma'arif NU Pandaan dengan umur 16 - 18 tahun. Teknik pengambilan sampel yang digunakan adalah random sampling, yaitu penentuan sampel secara rambang, setiap anggota populasi secara individual atau kolektif, diberi kesempatan sama untuk dapat menjadi anggota sampel (Suryabrata, 2013).

\section{Variabel dan Instrumen Peneitian}

Variabel yang diteliti pada penelitian ini adalah impulse buying. Impulse buying yang dimaksud dalam penelitian ini adalah suatu tindakan membeli karena barang tersebut memiliki harga yang rendah, adanya sedikit kebutuhan terhadap produk tersebut, ukurannya yang kecil, ringan dan mudah disimpan, terdapat pemasangan iklan, posisi barang, dan lokasi toko yang dekat. Sedangkan 
untuk gaya hidup hedonis adalah suatu kecenderungan yang nampaknya berorientasi pada kesenangan, perhatiannya ditujukan pada lingkungan luar, tidak mempunyai minat pada saudara sehingga merasa mudah mendapatkan teman tapi cenderung memilih-milih, selalu ingin menjadi pusat perhatian, waktu luangnya selalu digunakan untuk bersenang-senang serta tidak segan-segan membeli barang mahal.

Metode pengumpulan data dalam penelitian ini menggunakan skala impulse buying dan skala gaya hidup hedonis. Skala impulse buying disusun dengan model skala Likert yaitu terdapat 4 pilihan jawaban yaitu 0 untuk "sangat tidak setuju", 1 untuk "tidak setuju", 2 untuk "setuju", 3 untuk "sangat setuju". Jumlah total butir dalam skala ini sebanyak 22. Skoring dapat dilakukan dengan menjumlah total nilai tiap butir. Semakin tinggi total nilai maka semakin tinggi pula kecenderungan impulse buying.

Uji coba skala impulse buying pada 100 siswa secara umum karena skala ini tidak khusus digunakan untuk subjek tertentu.Indeks validitas dari skala ini adalah 0,310-0,593 dengan reliabilitas 0,797 . Validitas menggunakan pedoman yang menyatakan bahwa koefisien yang berkisar antara 0,30 sampai dengan 0,50 telah dapat memberikan kontribusi yang baik terhadap efisiensi suatu lembaga penelitian (Azwar, 2009). Melalui pedoman tersebut, dinyatakan bahwa semua butir pada skala valid.

Skala gaya hidup hedonis disusun dengan model skala Likert yaitu terdapat 4 pilihan jawaban yaitu 0 untuk "sangat tidak setuju", 1 untuk "tidak setuju", 2 untuk "setuju", 3 untuk "sangat setuju". Jumlah total butir dalam skala ini sebanyak 23. Skoring dapat dilakukan dengan menjumlah total nilai tiap butir. Semakin tinggi total nilai maka semakin tinggi pula kecenderungan gaya hidup hedonis.

Uji coba skala gaya hidup hedonis pada 100 siswa secara umum karena skala ini tidak khusus digunakan untuk subjek tertentu. Indeks validitas dari skala ini adalah 0,31-0,46 dengan reliabilitas 0,736 . Validitas menggunakan pedoman yang menyatakan bahwa koefisien yang berkisar antara 0,30 sampai dengan 0,50 telah dapat memberikan kontribusi yang baik terhadap efisiensi suatu lembaga penelitian (Azwar, 2009). Melalui pedoman tersebut, dinyatakan bahwa semua butir pada skala valid.

\section{Metode Analisa Data}

Penelitian korelasional dalam melakukan analisa menggunakan analisis regresi linier yaitu melihat hubungan antar variabel serta memprediksikan satu variabel (kriterium) dari variabel lainnya (prediktor).

\section{HASIL PENELITIAN}

Tabel 1. Deskripsi Subjek penelitian

\begin{tabular}{|c|c|c|}
\hline Variasi usia responden & Jumlah & Persentase \\
\hline 16 tahun & 26 & $26 \%$ \\
\hline 17 tahun & 33 & $33 \%$ \\
\hline 18 tahun & 41 & $41 \%$ \\
\hline
\end{tabular}


Gambaran demografi subjek penelitian dapat dilihat pada Tabel 1, berdasarkan tabel tersebut dapat diketahui bahwa subjek yang berpartisipasi dalam penelitian ini berjumlah 100 siswa dengan kisaran umur 16 tahun hingga 18 tahun. Subjek yang paling banyak berpartisipasi pada penelitian ini adalah subjek dengan usia 18 tahun dengan jumlah 41 orang (41\%) dari 100 responden.

Tabel 2. Kategori Impulse buying dari Hasil Skala Impulse Buying

\begin{tabular}{|c|l|c|c|c|}
\hline NO & \multicolumn{1}{|c|}{ Norma } & Kategori & Jumlah orang & Persentase \\
\hline 1. & $71 \leq$ & Tinggi & 30 & $30 \%$ \\
\hline 2. & $58 \leq \mathrm{x}<71$ & Sedang & 47 & $47 \%$ \\
\hline 3. & $\mathrm{x}<58$ & Rendah & 23 & $23 \%$ \\
\hline
\end{tabular}

Dari tabel 2 didapatkan gambaran bahwa dari 100 siswa yang berpartisipai dalam penelitian ini sebanyak 23 siswa atau $23 \%$ melakukan impulse buying pada kategori rendah, 47 siswa atau $47 \%$ melakukan impulse buying pada kategori sedang, dan 30 siswa atau $30 \%$ melakukan impulse buying pada kategori tinggi.

\section{Tabel 3. Kategori Gaya Hidup Hedonis dari Hasil Skala Gaya Hidup Hedonis}

\begin{tabular}{|c|l|c|c|c|}
\hline NO & \multicolumn{1}{|c|}{ Norma } & Kategori & Jumlah orang & Persentase \\
\hline 1. & $65 \leq$ & Tinggi & 25 & $25 \%$ \\
\hline 2. & $53 \leq \mathrm{x}<65$ & Sedang & 55 & $55 \%$ \\
\hline 3. & $\mathrm{x}<53$ & Rendah & 20 & $20 \%$ \\
\hline
\end{tabular}

Berdasarkan tabel 3 didapatkan gambaran bahwa dari 100 siswa yang berpartisipai dalam penelitian ini sebanyak 25 siswa atau 20\% melakukan gaya hidup hedonis pada kategori rendah, 55 siswa atau 55\% melakukan gaya hidup hedonis pada kategori sedang, dan 25 siswa atau 25 melakukan gaya hidup hedonis pada kategori tinggi.

Dari hasil perhitungan koefisien korelasi diperoleh hasil sebagai berikut :

Tabel 4. Tabel Perhitungan Koefisien Korelasi

\begin{tabular}{|c|c|c|c|c|c|}
\hline$\sum \mathrm{x}$ & $\sum \mathrm{y}$ & $\mathrm{r}_{\mathrm{xy}}$ & $\mathrm{r}_{\text {tabel } 5 \%}$ & $\mathrm{r}_{\text {tabel } 1 \%}$ & Kesimpulan \\
\hline 3278 & 3388 & 0,983 & 0.196 & 0.256 & $\begin{array}{c}\text { Ada korelasi yang sangat } \\
\text { signifikan }\end{array}$ \\
\hline
\end{tabular}

Dari analisis korelasi tersebut dapat diambil kesimpulan bahwa ada hubungan yang sangat signifikan, ditunjukkan dengan rxy yaitu 0,983 lebih besar dari nilai kritis tabel $1 \%$ sebesar 0,256. Artinya ada hubungan yang sangat signifikan antara gaya hidup hedonis dengan impulse buying. Dengan demikian dapat disimpulkan bahwa gaya hidup hedonis yang tinggi impulse buying cenderung tinggi, dan sebaliknya gaya hidup hedonis yang rendah impulse buying cenderung rendah. 
Tabel 5. Hasil Analisis Regresi Satu Prediktor

\begin{tabular}{|c|c|c|c|c|c|}
\hline $\begin{array}{c}\text { Sumber } \\
\text { Variasi }\end{array}$ & db & JK & RK/MK & Freg & F tab 1\% \\
\hline $\begin{array}{c}\text { Regresi (reg) } \\
\text { Residu (Res) }\end{array}$ & 1 & 22319059,84 & 22319059,84 & $89,65^{* * *}$ & 6,63 \\
& 10955301,28 & 11788,79 & & \\
\hline Total (T) & 99 & 33274361,12 & - & - & - \\
\hline
\end{tabular}

$* * *=$ sangat signifikan

Dari analisis regresi linier diperoleh $F_{\text {reg }}$ sebesar 89,65 dengan db 1 lawan 98 diperoleh $F_{\text {tabel }} 1 \%$ sebesar $6,63 . F_{\text {hitung }}<F_{\text {tabel }} 1 \%$, menunjukkan bahwa garis regresi sangat signifikan, artinya gaya hidup hedonis dapat memprediksikan Impulse Buying dengan kemampuan meramalkan (koefisien determinan) sebesar 96,63\%.

Hasil penelitian di atas sesuai dengan pendapatKuswardani (2010) bahwa model faktor-faktor yang mempengaruhi kegiatan belanja yang kaitannya langsung dengan kepribadian salah satunya adalah gaya hidup. Gaya hidup diartikan sebagai cara seseorang menggunakan waktu yang mengacu pada aktifitas, apa yang dipertimbangkan sebagai hal yang penting di lingkungannya, dan apa yang mereka pikirkan tentang dunia disekitarnya (Assael, 2009). Gaya hidup yang berkaitan langsung dengan aspek kesenangan dikenal sebagai gaya hidup hedonis. Keinginan konsumen untuk mencari kesenangan hedoniknya dalam berbelanja sering dikaitkan dengan pembelian impulsif (Anjani, 2012).

Selain itu, impulse buying juga dipengaruhi proses irasional yang mendesak kepuasan dan untuk memperoleh kesenangan secara spontan. Impulse membeli ini mungkin bermula merangsang konflik emosional dan cenderung terjadi diluar pemikiran yang irasional. Impulse buying merupakan kegiatan untuk berbelanja tanpa kontrol diri dengan sedikit atau tanpa pertimbangan mendalam. Alasannya adalah pengalaman emosional yang mendesak untuk untuk kesenangan semata. Akibatnya pembelian dilakukan untuk barang-barang yang sebenarnya tidak diperlukan. Hal tersebut sejalan dengan Semuel (2007) yang mengemukakan bahwa ketika terjadi pembelian impulsif akan memberikan pengalaman emosional lebih daripada rasional.

Loudon dan Bitta (Rachmawati, 2009) juga menjelaskan bahwa konsumen dalam pembelian impulsif mempunyai keinginan secara tiba-tiba untuk membeli, keinginan untuk membeli secara tiba-tiba tersebut menyebabkan konsumen berada dalam kondisi ketidakseimbangan psikologis yaitu kondisi sementara dimana konsumen kehilangan kontrol emosinya, konsumen yang mungkin mengalami konflik psikologis tersebut akan berjuang mempertimbangkan kepuasan, kegembiraan dan kesenangan dirinya, konsumen sering kali mengurangi evaluasi pengetahuan tentang produk dan terakhir konsumen seringkali membeli secara spontan 
tanpa mempertimbangkan konsekuensinya di masa depan.

Beberapa penelitian seperti yang dilakukan oleh Rachmawati (2009) menunjukkan bahwa faktor internal seperti hedonic shopping value dan emosi positif secara positif dan signifikan mempengaruhi pembelian impulsif.Sejalan dengan penelitian yang dilakukan oleh Premananto (2007) bahwa emosi seseorang saat berbelanja memiliki korelasi positif yang signifikan dengan kecenderungan melakukan pembelian impulsif. Menurut Park, et al.(2006) enosi merupakan efek dari mood yang menjadi faktor penting konsumen dalam melakukan keputusan pembelian. Faktor perasaan/emosi merupakan konstruk yang bersifat temporer karena berkaitan dengan situasi atau objek tertentu. Perasaan seperti jatuh cinta, senang, gembira, ingin memiliki, bergairah, terpesona, dan antusias akan mendorong seseorang untuk melakukan impulse buying. Hasil temuan Hausman (Rochman, 2009) mengindikasikan bahwa pengalaman berbelanja dapat mendorong emosi seperti perasaan ringan dan positif.

Emosi positif didefinisikan sebagai suasana hati yang mempengaruhi dan yang menentukan intensitas pengambilan keputusan konsumen.(Watson dan Tellegen dalam Tirmizi,et al., 2009). Emosi positif yang dirasakan konsumen akan mendorong konsumen untuk mengakuisisi suatu produk dengan segera tanpa adanya perencanaan yang mendahuluinya (impulse buying) dan sebaliknya emosi yang negatif dapat mendorong konsumen untuk tidak melakukan impulse buying (Premananto, 2007).

Selain itu, Rachmawati (2009) juga mengemukakan bahwa terdapat adanya faktor hedonic shopping motivation yakni motivasi belanja hedonis.Motivasi hedonis (Utami, 20 10:47) adalah motivasi konsumen untuk berbelanja karena berbelanja merupakan suatu kesenangan tersendiri sehingga tidak memperhatikan manfaat dari produk yang dibeli. Alasan dikembangkannya motivasi belanja adalah bahwa dalam aktivitas belanja seseorang termotivasi oleh berbagai kebutuhan psikologis disamping juga faktor dari nilai guna suatu produk.

Hal ini sesuai dengan yang dikemukakan oleh Semuel (2005) bahwa sebagian orang menganggap kegiatan belanja dapat menjadi alat untuk menghilangkan stres, menghabiskan uang dapat mengubah suasana hati seseorang berubah secara signifikan, dengan kata lain uang adalah sumber kekuatan. Kemampuan untuk menghabiskan uang membuat seseorang merasa berkuasa, senang dan hal tersebut menyebabkan terjadinya impulse buying.

Rachmawati (2009) juga menuturkan bahwa konsumen lebih mungkin terlibat dalam impulse buying ketika mereka termotivasi oleh keadaan hedonis atau alasan ekonomi, seperti kesenangan, fantasi dan sosial atau kepuasaan emosional. Menurutnya pula sejak tujuan pengalaman belanja untuk mencukupi kebutuhan hedonis, produk yang akan dibeli ini nampak seperti terpilih tanpa perencanaan dan mereka menghadirkan suatu peristiwa impulse buying. 
Temuan ini mendukung pernyataan Bloch et al., (1991) dan Roy (1994) dalam Park et al., (2006) yang mengatakan bahwa keterlibatan hedonis atau motivasi pengalaman berbelanja dapat memuaskan emosi atau kebutuhan berekspresi, seperti kesenangan, relaksasi dan kepuasan. Hausman dalam Park et al., (2006) menemukan perasaan yang positif dari konsumen seperti kesenangan erat kaitannya dengan pengalaman berbelanja hedonis dan aspek baru dalam belanja hedonis. Impulse buying dapat memenuhi hasrat hidup hedonis dan menciptakan keinginan untuk bersenang-senang dan kegembiraan (Hausman dalam Rohman,2009).

Berdasarkan beberapa uraian mengenai nilai hedonik tersebut dapat disimpulkan bahwa nilai hedonik merupakan perasaan emosional yang dirasakan konsumen dari pengalaman berbelanjanya yang lebih bersifat subjektif dan pribadi, bisa berupa kesenangan, kegembiraan dan kenikmatan. Impulse buying memiliki peran yang penting dalam memenuhi keinginan hedonis yang berhubungan dengan konsumsi hedonis.

\section{KESIMPULAN DAN IMPLIKASI}

Berdasarkan hasil penelitian dari 100 siswa yang berpartisipasi dalam penelitian ini dapat disimpulkan bahwa terdapat hubungan positif yang sangat signifikan antara gaya hidup hedonis dengan impulse buying pada remaja putri. Gaya hidup hedonis dapat digunakan untuk meramalkan impulse buying. Hal ini sesuai dengan hipotesis yang menyatakan bahwa gaya hidup hedonis dapat meningkatkan impulse buying pada kalangan remaja putri. Hal tersebut diperkuat dengan nilai $_{\text {rxy }}$ sebesar 0,983 dengan nilai kritis $r$ tabel $1 \%$ yaitu 0,256 dan nilai Freg sebesar 89,65 dengan nilai kritis Ftabel1\% yaitu 6,63 serta koefisien determinan sebesar 96,63\%.

Implikasi dari penelitian ini, yaitu bagi pendidik dapat menjadikan masukan sekolah guna untuk mengantisipasi adanya impulse buying pada siswa SMA Ma'arif NU Pandaan agar tidak menjadi perilaku yang berkelanjutan. Bagi siswa, impulse buying bukan merupakan cara pembelian yang dapat dianggap positif. Sehingga disarankan agar membiasakan untuk selalu membuat perencanaan dan melakukan pembelian berdasarkan kebutuhan.

\section{DAFTAR PUSTAKA}

Ancok, D. 2004. Psikologi Terapan: Mengupas Dinamika Kehidupan Umat Islam.(Cetakan Pertama). Yogyakarta: Darussalam Offset.

Anjani, Ni Luh Gde Geeta. (2012). "Pengaruh Fashion Involvement, Emosi Positif dan Hedonic Consumption Tendency Terhadap Pembelian Impulsif di Department Store”.Jogj akrta. Tesis Program Studi Magister Manajemen Program Pascasarjana, Universitas Atmajaya Jogjakarta.

Assael, H. 2009. Perilaku Konsumen Dan Marketing, Boston: Psw Kent. Publishing

Azwar, S. (2010).Metode Penelitian. Yogyakarta: Pustaka Belajar

Ekowati, T. (2009). Compulsive Buying : Tinjauan Pemasar dan Psikolog. Segmen Jurnal Manajemen dan Bisnis No. 08 
Januari 2009.Diakses melalui http://ejournal.umpwr.ac.id tanggal 21 Mei 2015.

Fitriani, Rahma. (2010). Studi Tentang Impulse Buying Pada Hypermarket di Kota Semarang, Fakultas Ekonomi Universitas Diponegoro, Semarang

Gültekin, B., dan Özer L., 2012, The Influence of Hedonic Motives and Browsing On Impulse Buying, Journal of Economics and Behavioral Studies, Vol. 4, No. 3, Maret: pp. 180-189, (ISSN: 2220-6140)

Haq, A.A. (2013). "Pengaruh Sales Promotion Terhadap Perilaku Impulse Buying Wanita Bekerja Pada Matahari Department Store Plaza Citra Pekanbaru".Jurnal Jurusan Ilmu Komunikasi Fakultas Ilmu Sosial dan Ilmu Politik Universitas Riau.Pekanbaru.

Hausman, A. (2000), "A multi-method investigation of consumer motivations in impulse buying behavior", Journal of Consumer Marketing, Vol. 17 No. 5,pp. 403-419.

Hawkins, D.I., Mothersbaugh, D.L., \& Best, R.J., (2004). Consumer Behavior: Building Marketing Strategy (10th Ed.). New York: The McGraw-Hill Companies, Inc.

Hirschman, E.C. dan Holbrook, M.B. (1982). The experiential aspects of consumption: consumer fantasies, feelings and fun, Journal of Consumer Research, Vol. 9 (No. 2) pp. 132-40

Hurlock, E. B. Alih Bahasa: Istiwidayanti dan Soedjarwo (1999).
Sepanjang Rentang Kehidupan. Jakarta: Erlangga

Kharis, Ismu Fadli. (2011). Studi Mengenai Impulse Buying Dalam Penjualan Online (Studi Kasus di Lingkungan Universitas Diponegoro Semarang, Semarang.

Kotler, P. (2001). Manajemen Pemasaran. Jilid 1 .Jakarta Erlangga.

Kuswardani, I \& Sholihah, N. A . (2005). Hubungan Antara Gaya Hidup Hedonis Dan Konformitas Teman Sebaya Dengan Perilaku Konsumtif Terhadap Ponsel Pada Remaja (Jurnal)

Loudon, D. \& Bitta, A. (1993). Dalam Hubungan Antara Gaya Hidup Hedonis Dengan Kecenderungan Impulse Buying Produk Pakaian Imitasi Pada Pria Homoseksual Di Malang Raya

Lumintang, Fenny F. (201 0).Pengaruh Hedonic Motives Terhadap Impulse Buying Melalui Browsing Dan Shopping Lifestyle Pada Online Shop (Jurnal)

Mangkunegara, A. (2005). Perilaku Konsumen. Bandung: Refika Aditama.

Mardiati, L \& Hermina T. (2004).Pengaruh Hedonic Shopping Motivations Terhadap Impulse Buying Behavior (Jurnal)

Martha, S H. dan Setyawan, I. (2010). Correlation Among Self-Esteem with A Tendency Hedonist Lifestyle of Students At Diponegoro University. (Jurnal)

Masmuadi, A. (2007). Hubungan Antara Konsep Diri Dengan Kecenderungan 
Gaya Hidup Hedonis Pada

Remaja.Skripsi. Universitas Islam

Indonesia.Diakses

melaluihttp://psychology.uii.ac.id

tanggal 6 Mei 2015.

Mowen, J.C \& Minor, M. 2002.Perilaku konsumen.Jilid 1. Edisi Kelima. Jakarta: Erlangga

Papalia, D. E., dkk.(2008). Human Development (Psikologi Perkembangan) Edisi Kesembilan. Boston: McGrawHill.

Praja, D. D \& Damayanti A. (2004).Potret Gaya Hidup Hedonisme Di Kalangan Mahasiswa (Jurnal)

Rahmasari, Lisda. (2010). "Menciptakan Impulse Buying”, Jurnal Majalah Ilmiah Informatika Vol. 1 No. 3

Rachmawati, Mira A. (2007). Hubungan Antara Konsep Diri Dengan Kecenderungan Gaya Hidup Hedonis Pada Remaja (Jurnal)

Rachmawati, Veronika. (2009). Hubungan Antara Hedonic Shopping Value, Positive Emotion, Dan Perilaku Impulse Buying Pada Konsumen Ritel, Jurnal Majalah Ekonomi.

Rianton, R. (2013). "Hubungan Antara Konformitas Teman Sebaya Dengan Gaya Hidup Hedonis Pada Mahasiswa Kab.Dhamasraya di Yogyakarta”. Jurnal Fakultas Psikologi Universitas Ahmad Dahlan. Yogyakarta

Rohman, F., 2009, Peran Nilai Hedonik Konsumsi dan Reaksi Impulsif sebagai Mediasi Pengaruh Faktor CEKonal terhadap Keputusan Pembelian Impulsif di Butik Kota Malang, Jurnal Aplikasi Manajemen .

Santrok, J. W. (2007). Remaja Edisi 11 Jilid 1. Jakarta: Erlangga

Sarwono, S.W. 1989. Psikologi remaja.Raja Grafindo Persada. Jakarta.

Semuel, H., 2007, Pengaruh Stimulus Media Iklan, Uang Saku, Usia, dan Gender Terhadap Kecenderungan Perilaku Pembelian Impulsif (Studi Kasus Produk Pariwisata), Junral Manajemen Pemasaran Vol. 2, NO. 1, April: pp 31 42.

Sugiyono. (2007). Metode Penelitian Bisnis: Pendekatan Kuantitatif, Kualitatif, dan R\&D (16th ed.). Bandung: Alfabeta.

Suryabrata, S. (2013).Metode penelitian. Jakarta: Rajawali Pers.

Susanto, A.B. 2001. Potret-Potret Gaya Hidup Metropolis. Jakarta: Kompas.

Silvera, David H., Anne M. Lavack, Fredric Kropp. Impulse Buying: The Role Of Affect, Social Influence, And Subjective Wellbeing. Journal of Consumer Marketing,

Utami, Christina Widya. (2010). Manajemen Ritel: Strategi dan Implementasi Operasional Bisnis Ritel Modern di Indonesia, Edisi 2, Penerbit Salemba Empat, Jakarta

Widawati, L. (2011). Analisis Perilaku "Impulse Buying" dan "Locus of Control" Pada Konsumen di Carrefour Bandung.Mimbar. XXVII, 2 (Desember 2011), 125-132. Fakultas Psikologi Universitas Islam Bandung. Bandung. 
http://mimbar.lppm.unisba.ac.id tanggal 
